\title{
Hobart, Tasmania: Antarctic and Southern Ocean connections
}

\author{
Lorne K. Kriwoken
}

Centre for Environmental Studies, University of Tasmania, GPO Box 252C, Hobart, Tasmania 7001, Australia

\section{John W. Williamson}

\author{
Department of History, University of Tasmania, GPO Box 252C, \\ Hobart, Tasmania 7001, Australia
}

Received May 1992

\begin{abstract}
This paper describes the historical and contemporary associations between Hobart (Tasmania, Australia) and Antarctica and the Southern Ocean. This association is traced from the sealing and whaling industry, through early exploration and scientific expeditions, to contemporary issues of institutional and educational development and tourism. It is argued that this polar link has placed Hobart at the centre of some important Antarctic and Southern Ocean developments.
\end{abstract}

Introduction

Sealing and whaling

Exploration

Sovereignty and science

Ocean and air links

Education and research

Conclusion

Acknowledgements

References

\section{Contents}

93

93

95

98

99

100

101

101

101

\section{Introduction}

Hobart, Tasmania, the capital city of the island state of Australia, has long been associated with significant milestones in Antarctic history (Fig. 1). Beginning with the sealing and whaling industries of the early $1800 \mathrm{~s}$, Hobart (known at the time of its settlement in 1803 as Hobart Town) established itself as a safe port with ample provision for refitting vessels that plied the Southern Ocean. Hobart's polar connection was firmly established when the port was used for supplying exploration and scientific expeditions, first in search of a southern continent and then to Antarctica. Hobart's involvement with Antarctica increased in the twentieth century when issues of sovereignty, scientific programs, and institutional development became more prominent. These historical and contemporary polar links make Hobart an important centre for activities in greater Antarctica and in the Indian Ocean sector of the Southern Ocean.

\section{Sealing and whaling}

Predating the commencement of the sub-Antarctic sealing industry by almost a century and a half was the Netherlands expedition from Djakarta (then known as Batavia). Abel Janszoon Tasman with Heemskerck and Gerrit Janszoon with Zeehaan took possession of Tasmania, which they named Van Diemen's Land, on 24 November 1642. Although not directly linked with sealing exploitation these 'major discoveries substantially reduced the size of the mythical great Southern Continent' (Headland 1989: 63).
Captain James Cook also performed a similar role in defining the southern continent when he circumnavigated the world at high southern latitudes and crossed the Antarctic Circle between 1772 and 1775. In 1773 Cook, with Resolution and Discovery, moored in Adventure Bay off Bruny Island in southern Tasmania. Cook did not believe that a continent existed in the areas in which he had sailed, but, if one did exist, that it must be within the Antarctic Circle, that it was practically inaccessible, and that it would most likely be a barren waste of snow and ice. It was Cook's reports about the huge seal colonies on the subAntarctic islands that provided the incentive for the British sealing industry in these areas. Because of this, Tasmania (which remained Van Diemen's Land until 1856) began its links with the Southern Ocean through the sealing and whaling industries. Enderby Brothers, a British mercantile firm, worked the Southern Ocean from 1785, and Britannia, the first ship to hunt whales in Australian waters, saw sperm whales off the southwest cape of Tasmania in 1791. A British mercantile voyage from Bristol, led by Charles Bishop in Ruby and Nautilus (1794-1799) sailed across the Pacific Ocean from Drake Passage to Kamchatka and from Alaska to Tasmania. The voyage included a pioneer sealing venture in the Bass Strait for the Canton trade. From 1798-1799 they took 9000 fur seal skins (Headland 1989: 87).

Although there was early British interest in sealing, it was the presence of Americans that was most significant. The first American vessel in these waters was Alliance in 1787. During the 1790s other New England sealers and whalers sailed in Australian waters, used the many anchorages in the Derwent, and called at Hobart (Wace and Lovett 1973: 2,9). Almost half (46.4\%) of the individuals engaged in the sub-Antarctic sealing industry between 1786 and 1928 were Americans, followed by the British (19.1\%), those from New South Wales (9.0\%) and Tasmanians (1.5\%) (Headland 1989: 41).

Five whalers accompanied the Royal Navy's Third Fleet that brought convicts to Australia, indicating the British government's desire for some financial recom- 


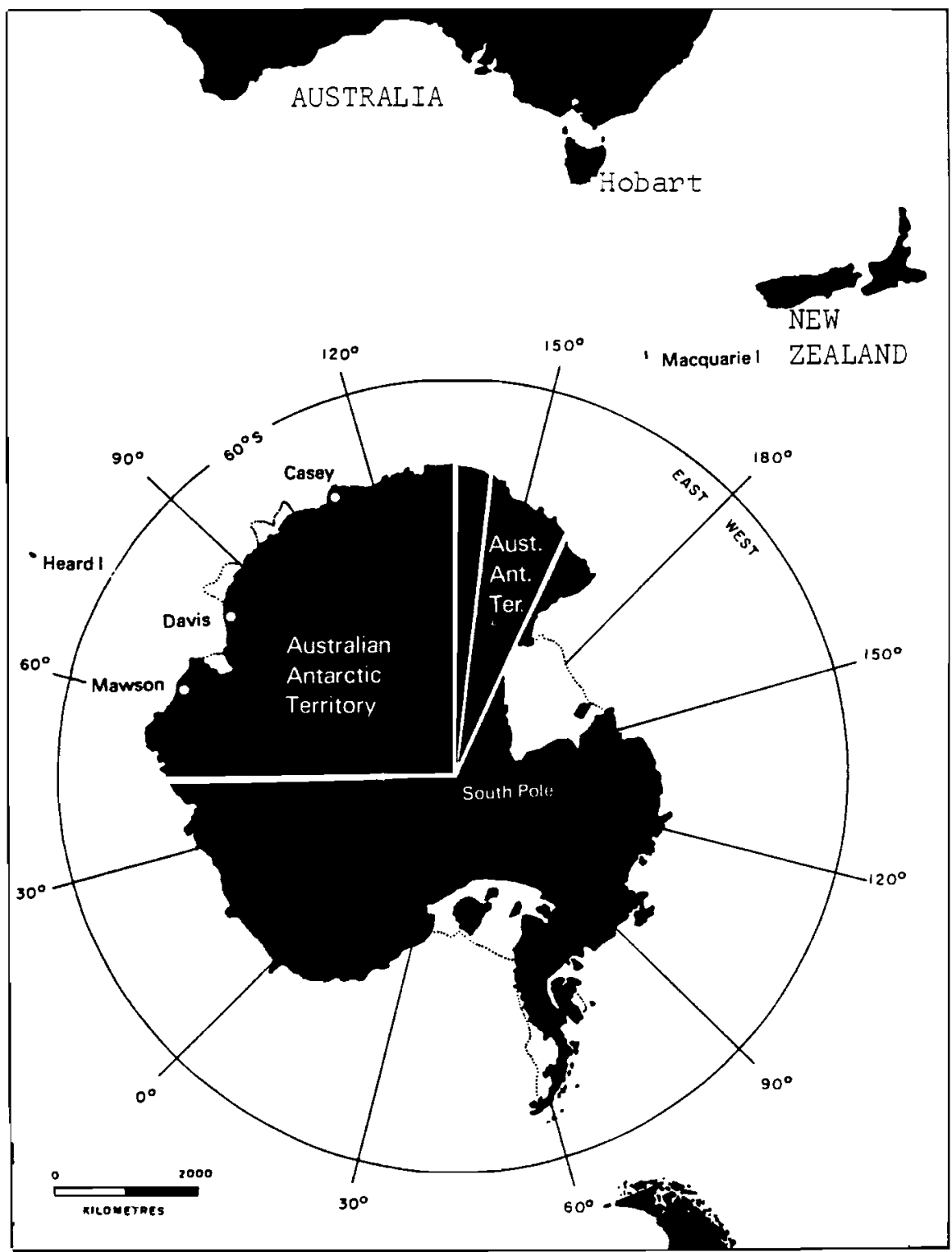

Fig. 1. Location of Hobart, Tasmania, the Southern Ocean, and the Australian Antarctic Territory.

pense from the new colony. In 1803 Lieutenant John Bowen aboard Lady Nelson took possession of Tasmania and established the first European settlement near Hobart. Eber Bunker, captain of the whaler Albion, accompanied the British expedition to settle on the Derwent River and took three whales during the voyage to Tasmania(Historical Records of Australia 1921: 197). The arrival of Bowen was actually predated by one year by the French naval expedition of Nicolas Baudin and Géographe, Naturaliste, and Casuarina, which made surveys and scientific observations in Tasmania from January to March 1802.

Tasmania became a major centre for the southern whaling and sealing trades for much of the rest of the century (Headland 1989: 93), and the founding of Hobart Town in 1804 opened a new era of exploitation in the region. Eventually Hobart Town became a more important whaling centre than Port Jackson, New South Wales. Jørgen Jørgenson, a Danish adventurer and chief officer of
Alexander, claimed to have taken the first whale in the Derwent River in 1804. In 1805 and 1806 the Enderby Brothers' whaling vessel Ocean again sailed into Tasmanian waters.

Sealers from many nations, in their efforts to find new areas to work, discovered, rediscovered, or explored new lands. One of these was was Macquarie Island, which was first sighted on 20 July 1810 by a sealing crew on the brig Perseverance (Cumpston 1968: 6).

In 1813 Captain James Kelly, with Mary and Sally, led a pioneering sealing expedition out of Sydney via Tasmania, and the next year Philip Goodenough headed a similiar expedition. The first oceanic whaling vessel from the United States, Adamant, called at Hobart in 1816 and during the next seven years more than 300 vessels entered the port. Vessels from Hobart worked all the way from Antarctic waters north to Kodiak Bay, Alaska (Headland 1989: 107). A Tasmanian sealing voyage from Hobart under Daniel Taylor in Caroline visited the South Shetland Islands in 1821-1822 (Headland 1989: 122). During 1825 and 1826 James Craig, followed by John Lovett, led further sealing expeditions out of Hobart. When Tasmania was proclaimed a separate colony in 1825 , Macquarie Island was included as a dependency. In 1826 the Derwent Whaling Club was formed, and within a few years deepsea whaling off Tasmania had begun. Whale products became the colony's chief export, surpassing wool (Abbott and Nairn 1969: 298-303).

Despite duties and port charges on whale oil being extraordinarily high, the amount of whale oil exported from Hobart increased from 179 tons in 1827 to 713 tons in 1830 (Lawson 1986: 51). In 1834 there were seven whaling ships operating out of Hobart, and the total export of whale oil that year was valued at $\mathfrak{1 4 5 , 5 7 3}$ (Lawson 1986: 53). In 1834 there were an estimated 50 American and French whalers in Tasmanian waters, and it was decided by the Lietutenant Governor that Hobart should attempt to attract even greater fleets of whalers that would use the port for refitting and for the shipment of their oil (Lawson 1986: 59). Port duties were reduced and some other duties were exempted. This prompted a great in- 
crease in activity, and the number of foreign vessels using Hobart as a base for sealing and deep-sea whaling rose significantly. On Good Friday, 1847, there were 37 foreign whaling ships in Hobart, and, on one day in 1850, 44 whaling vessels were anchored in the Derwent River.

\section{Exploration}

By the 1830 s exploration and science had begun to lure vessels to Hobart and the Southern Ocean. In 1830 John Biscoe was sent by Enderby Brothers to look for new sealing grounds (Savours 1983: 485). Commanding the brig Tula and accompanied by the sloop-rigged cutter Lively, he left England on 4 July 1830 and arrived at the Falkland Islands by November of that year. During the next six months he sailed east and south to the Antarctic continent, sighting Enderby Land in February 1831. Tula was blown northwest by a terrible storm, and Biscoe decided to run for Tasmania, where he arrived on 10 May 1831. Tula was repaired and the sick crew recuperated. After several months Biscoe left on another voyage to the south and sighted the Antarctic Peninsula in February 1832. Biscoe was convinced that what he had seen were parts of a continent (Savours 1983: 487; 1992: 181). In 1837 he brought his wife to live first in Sydney and then, soon after, in Hobart. For several years he served as the master of various vessels working along the Australian coast, but poor health forced his retirement in 1841 , and in 1843 he left for England, dying during that voyage (Savours 1983: 490; 1992: 182).

Tasmania's role in exploration and scientific interest in the Antarctic increased with the arrival, in 1837, of Sir John Franklin as Lieutenant Governor. In 1839 a French expedition under Dumont d'Urville spent time in Hobart (his third visit) to recruit additional crew members for a journey to the South Magnetic Pole. Dumont d'Urville travelled widely throughout the colony. Some of his crew climbed Mount Wellington and declared it as unquestionably the finest view anywhere (Rosenman 1987: 454). Franklin and his wife Jane entertained their French guests brilliantly, directed the repair of their craft, and saw to the well-being of the French crew, many of whom had suffered terribly from dysentery as a result of fouled water taken on at Lampung Bay in the Indonesian archipelago. Upon leaving Tasmania, the French sailed south and, early in 1840 , sighted land. They charted this previously unexplored coast, which was called Terre Adélie, and they came close to, although they did not attain, the South Magnetic Pole (Rosenman 1987: 479-492).

Interest in science and exploration was further heightened in the colony when a British expedition under James Clark Ross, Franklin's friend and fellow Arctic explorer, sailed into Tasmanian waters. The expedition aimed to study terrestrial magnetism (an important scientific issue in the 1830s), to discover new lands, and to correct charts of existing discoveries (Lovering and Prescott 1979: 120). Ross' ships Erebus and Terror, the latter commanded by Francis Crozier, entered the Derwent River on 16 August 1840. The expedition spent the winter in Hobart, and, with the help of convict labour, the crew constructed a magnetic observatory in the grounds of Government House. The work was personally supervised by Franklin and was completed in nine days (Ross 1982: 64). The remains of this, the Rossbank Observatory, are still visible (Savours 1992: 175).

In Hobart, Ross learned of the discoveries by Dumont d'Urville and Charles Wilkes (of the United States Exploring Expedition, 1838-1842) and so decided to choose a different route to the south than originally intended. During the stay in Hobart the ships were refitted, stores were bought, and the crew was entertained by the local community (Winter 1992). The ships sailed from Hobart on 12 November 1840 on their first Antarctic voyage. Although the South Magnetic Pole was not attained, the members of the expedition accomplished a great deal of other exploratory work and made measurements of the magnetic field (Savours 1992: 176). The expedition returned during early April 1841 (Hobart Town Advertiser 27 April 1841), and Franklin commented upon the good condition of the officers, crew, and ships. Ross' report played an important role for later expeditions led by Carsten E. Borchgrevink, Robert Falcon Scott, Ernest Shackleton, and Roald Amundsen.

In fact, the impact of Ross and Crozier's discoveries was sufficient that a play, probably the first about the Antarctic, was written and performed about the expedition. Named Antarctic expedition, it was performed at the Royal Victoria Theatre in Hobart on 3 May 1841 and was described as a 'grand nautical drama,' although it failed to impress the critics (Hobart Town Advertiser 4 May 1841). Officialdom made good use of the presence of the expedition, and when the foundation stone of the new Government House was laid, with Ross and Crozier present, the gun salute was offered by Erebus and Terror.

The good feeling that developed between the members of the expedition and the local citizens was evident, and, after a ball held aboard Erebus and Terror, on 1 June 1841, the officers thanked the civil and military officials for the kind attentions shown them during their stay (Hobart Town Advertiser 4 June 1841). On 7 June Erebus and Terror sailed out of the Derwent River on the way to southern waters via New Zealand.

The Tasmanian Journal of Science published a series of articles about the expedition (1842-1849) and encouraged Australians to take a scientific interest in the Antarctic. After the US report of Heard Island in November 1853 , whaling and sealing expeditions from Tasmania increased for a number of years. In $1858 \mathrm{Dr}$ Crowther sent two vessels, Offley and Elizabeth Jane of Hobart, to take whales and seals off Heard Island.

Following this flurry during the 1850 s there was a lull in exploitation and exploration for nearly 30 years. Poor returns from both whaling and sealing, financial difficulties for many governments, and imperialist efforts in Africa and Asia kept interest in the Southern Ocean to a minimum. However, the 1880 s began a period during which parties concentrated on exploring parts of the Antarc- 
Table 1. Significant dates in the Hobart connection with Antarctica and the Southern Ocean

1642: Abel Janszoon Tasman with Heemskerck and Zeehaan named and took possession of Van Diemen's Land (Tasmania) on 24 November.

1773: Captain James Cook with Resolution and Discoverycrossed the Antarctic Circle. Cook moored in Adventure Bay off Bruny Island during the second voyage.

1794-1799: British mercantile voyage from Bristol with Charles Bishop included a pioneer sealing venture with Nautilus in Bass Strait for the Canton trade.

1802: French naval expedition with Nicolas Baudin and Géographe, Naturaliste, and Casuarina made surveys and scientific observations in Tasmania, January-March.

1803: Under instructions from Governor Philip King of New South Wales, Lieutenant John Bowen took possession of Tasmania and established the first European settlement near Hobart. Tasmania becamea majorcentre for sealing and southern whaling trade for the rest of the century.

1816: The first oceanic whaling vessel, Adamant (USA), visited Hobart, and from 1816 to 1823 more than 300 vessels used the port, most involved in whaling and sealing.

1816: James Kelly led sealing expedition into the Southern Ocean. Kelly returned to settle in Hobart.

1821-1822: Tasmania sealing voyage from Hobart with Daniel Taylor and Caroline visited the South Shetland Islands.

1825: George Todd in Cyprus led a relief expedition to Macquarie Island in search of Caroline.

1825: Macquarie Island made a dependency of Tasmania.

1830-1832: British sealing expedition from London led by Captain John Biscoe in Tulacalled into Hobart in 10 May 1831, with the crew suffering from scurvy.

1831: Samuel Harvey in Venusled a sealing and whaling expedition out of Hobart to the Ross Sea and Macquarie Island.

1840-1841: Sir James Clark Ross with ships Erebus and Terror called into Hobart to recruit crew and established a magnetic observatory.

1855-1857: Tasmanian sealing voyage with Joseph Kennedy and Plumstead visited lles Kerguelen.

1894: Norwegian Henrick Bull in Antarctica sailed from Hobart on 3 October and made the fourth recorded landing on the Antarctic continent at Cape Adare in the Ross Sea.

1898: Tasmanian Louis Bernacchi was a member of the British expedition led by Carsten E. Borchgrevink (a Norwegian, resident in Australia) in Southern Cross. The expedition called at Hobart on 28 November en route to Cape Adare. This was the first expedition to winter ashore. They returned to Hobart on 16 April 1900.

1901-1904: Robert Falcon Scott in Discovery led another expedition with Tasmanian Louis Bernacchi as a member.

1910-1912: Norwegian Roald Amundsen in Fram led an expedition that reached the South Pole on 14 December 1911. Fram returned to Hobart on 7 March 1912, and Amundsen transmitted the story of his success to the rest of the world.

1911-1914: Australasian Antarctic Expedition led by Douglas Mawson in Aurora set out from Queen's Wharf, Hobart on 2 December 1911. Returned twice to Hobart, on 14 December 1912 and 14 March 1913.

1914-1916: British Imperial Trans-Antarctic Expedition called into Hobart December 1914 aboard Aurora.

1929-1931: British-Australian-New Zealand Antarctic Research Expedition led by Douglas Mawson called into Hobart in November 1930 and March 1931.

1933: Australian Antarctic Territory established.

1933: Tasmanian government declared Macquarie Island a wildlife sanctuary.

1938-1939: United States expedition led by Lincoln Ellsworth in Wyatt Earp with Australian Hubert Wilkins called into Hobart during February. This expedition included the first flights over the South Pole.

1948: ANARE established, with most expeditions leaving from Hobart.

1953: The ships of the Danish Lauritzen line chartered by Australia; the first was Kista Dan.

1981: Australian Antarctic Division transferred to Hobart.

1982: CCAMLR secretariat established in Hobart.

1987: Nella Dan left Macquarie Wharf in Hobart for the last time on 27 November. The ship was blown onto rocks off Macquarie Island on 3 December 1987 and was scuttled on 24 December 1987.

1988: Institute of Antarctic and Southern Ocean Studies was established at the University of Tasmania.

1990: Australia's first icebreaker, Aurora Australis, left on her maiden voyage from Hobart on 9 October.

1990: Australian Antarctic Foundation established in Hobart.

1991: Cooperative Research Centre for the Antarctic and Southern Ocean Environment announced for Hobart. The CRC is responsible for coordinating Antarctic research between scientific institutes throughout Australia.

tic coast and frequently wintered there.

The idea of an all-Australian Antarctic expedition came about during the 1880s. The Geographical Society of Victoria set up an Antarctic Exploration Committee in May 1886 to inform people about the Antarctic and to organize an Australian expedition (Cole 1990: 21). Due to insufficient funds and lack of suitable captains, crews, and vessels, nothing happened for more than 20 years, until 1911, when Douglas Mawson led the first Australian expedition to the Antarctic.
Tasmania's Antarctic links also became literary when Christopher Spotswood published an early novel about the far south. It was entitled The voyage of Will Rogers to the South Pole and was published in Launceston in 1888.

One of the early parties to set foot on the Antarctic continent was that led by Henrik J. Bull aboard Antarctic, which arrived in Hobart during September 1894. While the captain of the ship, Leonard Kristensen, was showing local dignitaries over Antarctic, Bull and Borchgrevink (a school friend of Amundsen), spoke to a reporter from The 

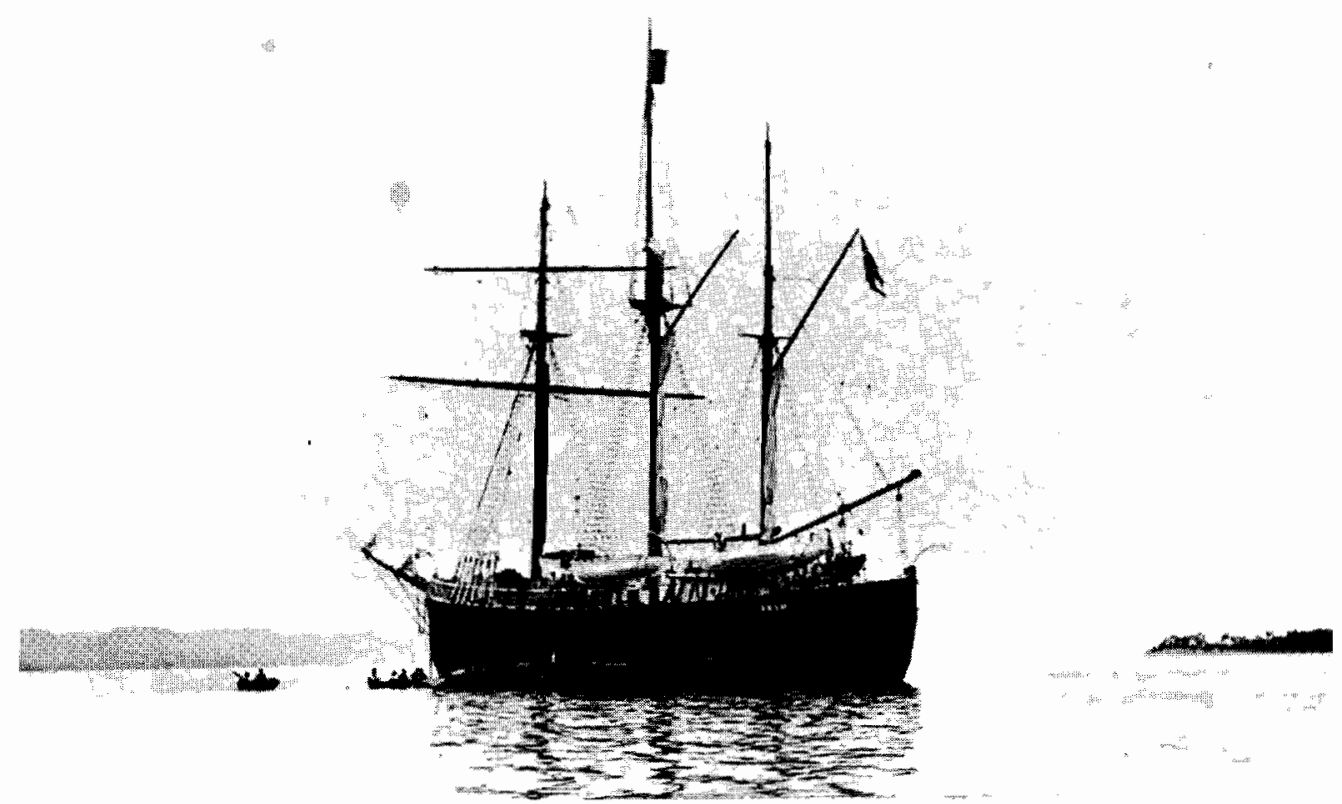

Fig. 2. Fram moored off Sandy Bay after Amundsen's successful journey to the South Pole.

Mercury. Bull began by refusing to say whether or not he thought Hobart would become the Australian depot for Antarctica. However, he was impressed with the facilities for refitting and the high quality of the whaling gear made in Hobart. He also feared that, as Tasmania was scenically like Scandinavia and as many of the sailors had not signed a contract for the entire voyage, this was the sort of place in which they would be tempted to 'clear' the vessel permanently. Bull was at pains to say how this was simply a commercial voyage to hunt for whales.

However, this image of a purely commercial voyage was tempered by the presence of Borchgrevink, a scientist whose main field of interest was the Antarctic. Borchgrevink was signed on to the crew as a supernumerary but admitted that despite the commercial nature of the voyage he hoped to gain scientific information that could be used by later expeditions to the Antarctic. Antarctic sailed south on 3 October 1894, and on 23 January 1895 the party landed at Cape Adare. Although some have credited this group with being the first to land on the Antarctic continent (Capricorn Press 1985: 129), others have pointed out that it was the second known landing on Victoria Land and there had been at least four previous landings on the Antarctic continent (Headland 1989: 216).

After this journey Borchgrevink was inspired to return to the Antarctic. He offered himself as leader of an expedition to Cape Adare, where he proposed to winter (Evans and Jones 1975; Huntford 1979: 60). He received financial backing from Sir George Newnes, a British publisher, and, as head of a British expedition that included Louis Bernacchi, a Tasmanian physicist, sailed south in 1898 aboard Southern Cross. Borchgrevink called al Hobart on 28 November 1898. During the stay of a little more than a fortnight, the members of the expedition were feted by Hobart's residents. There were garden parties, visits to the interior of the island, huge receptions, and many speeches. In one reception at the Hobart Town Hall there were speeches by the Treasurer, Bishop Montgomery, and the Governor, Lord Gormanston. Bernacchi also spoke at the reception, paying tribute to Tasmania and saying that this present expedition would usher in a bright new era of scientific research and geographical discovery. The Mercury challenged the expedition with finding an answer to whether there was an Antarctic continent or whether it was, in fact, an archipelago (The Mercury 30 November 1898). The crew placed a wreath at Franklin Square as a tribute to the memory of Sir John Franklin, and departed on 17 December 1898. During 1899 they wintered at Cape Adare - the first scientific party to winter on the continent - and they returned to Hobart on 16 April 1900. Thus a Tasmanian scientist became the first Australian to winter in Antarctica.

Once, Tasmania had provided only wharf facilities and other services to vessels heading south; now Tasmanians were becoming involved in the voyages themselves. Bernacchi's account of this, and other expeditions, stimulated in Tasmanians a fascination for the Antarctic (Bernacchi 1901). Antarctic exploration from Hobart had become a Tasmanian concern, not just a British one.

The British National Antarctic Expedition led by Scott during 1901-1904 again included Bernacchi as a physicist. Although some have portrayed the results of this ambitious expedition as somewhat disappointing (Scholes 1953: 71), it did produce 24 volumes of scientific results.

The next involvement of Hobart with Antarctic discovery was Roald Amundsen's South Polar expedition of 1910-1912. Amundsen and four of his companions reached the South Pole on 14 December 1911 and returned via Hobart. On 8 March 1912 The Mercury reported that an auxiliary barquentine of 402 tons had arrived, the day before, from Antarctica. This vessel was Fram (Fig. 2). The expeditioners remained incommunicado (Fram did nol dock, and dropped anchor off Sandy Bay) for several days while Amundsen fulfilled obligations to financial 


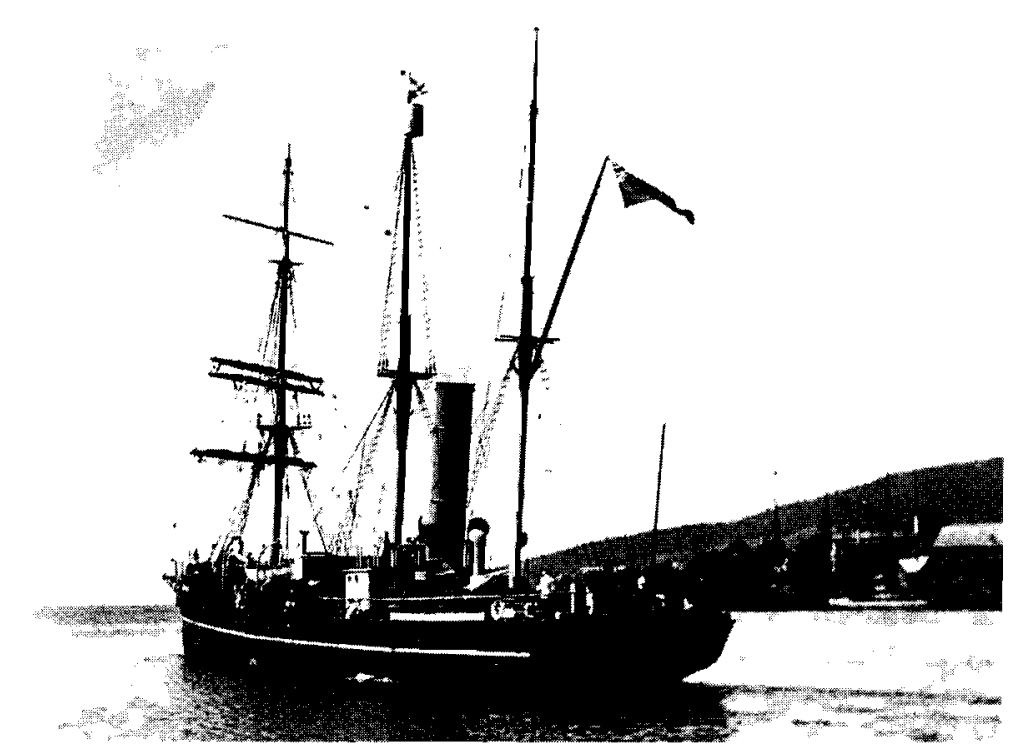

Fig. 3. Aurora leaving Hobart.

supporters. He came ashore, stayed at Hadleys Hotel, and sent a telegram to Christiana (Oslo) to announce that he had succeeded in reaching the Pole. Amundsen had experienced difficulties with telegrams from Alaska after completing the Northwest Passage (1901-1904), so this time he entrusted the important message to the Manager of Telegrams, Mr Bowden. The story of the expedition that appeared in The Daily Chronicle of London was reprinted in The Mercury on 9 March. Finally, Amundsen broke his embargo and invited a Mercury reporter aboard Fram. In addition, Amundsen engaged J.W. Beattie, a highly regarded local photographer, to develop the plates from the expedition.

A round of dinners, speeches, and honours awaited the crew. Some members watched yacht races on the Derwent, and Amundsen was made an honorary member of the Derwent Sailing Squadron. Hobart, by its proximity to the Antarctic continent, proved to be the ideal location from which Amundsen could send the telegram reporting his achievements. Breaking this news of his success to the world, ahead of Scott, had become almost as important to Amundsen as winning the race to the Pole. The local newspapers prided themselves that 'to Hobart has fallen the distinction of being the port from which the news of this successful enterprise has been sent to all parts of the world' (The Mercury 11 March 1912).

Fram left Hobart on Wednesday, 19 March 1912, for Buenos Aires, but even that event was overshadowed by the return of Aurora from Antarctic waters. Hobart was a vital link for Mawson's Australasian Antarctic Expedition (1911-1914). In November 1911 he and expedition secretary Conrad Eitel arrived and joined Aurora and her crew (Fig. 3). The departure date had been set for 2 December 1911 , but there was a vast amount to do before then. More than 5000 packages had to be sorted out in the sheds of Queen's Wharf. Charles Laseron, expedition biologist, remembered that the expedition members were so keen to help that the wharf labourers almost held a demarcation strike (Laseron 1947: 22).

Aurora was overhauled and repairs completed in rapid time. A special service for the expedition was held in St David's Cathedral on Sunday, 26 November 1911. On the specified date, 2 December, at 4:00 PM, final best wishes were extended from the Governor of Tasmania, Sir William Macartney (whose wife was Scott's sister), and Aurora stood off Queen's Wharf. The crew and expeditioners looked back to the stately mass of Mount Wellington, and some of the younger members called Hobart the land of strawberries and cream (Mawson 1915: 25). Mawson left a radio party on Macquarie Island so that they could relay messages from the Antarctic to Hobart. This was the first time radio had been used in this way in Antarctic exploration. Aurora returned to Hobart during December 1912 and spent the winter in Cornelian Bay. After relieving the expedition's western party she returned again to Hobart in March 1913. On Christmas morning 1914 Aurora left Hobart for the Ross Sea with members of Shackleton's Imperial TransAntarctic Expedition. This party was to lay depots for Shackleton's group that planned to cross the continent. However, awful problems beset both groups and the expedition failed in its main objectives.

\section{Sovereignty and science}

Apart from Norwegian whaling expeditions to the Ross Sea (1923-1924), which included the Tasmanian sailor and press correspondent Allan Villiers, Hobart had to wait until 1930 before it was reassociated with the Antarctic continent. In November 1930 Mawson's British, Australian and New Zealand Antarctic Research Expedition (BANZARE 1929-1931) party on Discovery arrived in Hobart after charting part of the Antarctic coastline and then returning to Adelaide and Melbourne. She refitted in Hobart and left for the second voyage on 22 November 1930, visiting Macquarie Island before reaching Cape Denison. From there she sailed west, and the party made several landings on the continent carrying out valuable scientific work. This expedition was also an exercise in flag-waving and empire-building, and British territory in the Antarctic was increased (in 1933 the Australian Antarctic Territory was established). For more than a century Hobart had been involved with exploitation and exploration in the Southern Ocean and Antarctic continent. However, when, in 1933, the Tasmanian government declared Macquarie Island a sanctuary, Hobart's role incorporated, for the first time, environmental protection and conservation.

After the second voyage of BANZARE, Discovery returned to Hobart on 19 March 1931. Mawson's successful expeditions had formed the basis for Australian claims to Antarctic territory at a time when many nations were endeavouring to establish sovereignty over various parts 
of the continent. The Australian government, through the Department of External Affairs, acquired Wyatt Earp in 1939 for $£ 4400$ as a vessel for the survey of the George V Land coastline so as to consolidate its claim.

During World War II the threat of German raiders at Iles Kerguelen meant that Hobart authorities felt it necessary to mine the mouth of the Derwent River. After the war, however, research was re-established more strongly than ever. In 1947 the first of the Australian National Antarctic Research Expeditions (ANARE) was mounted, with stations established on Macquarie Island and Heard Island. In 1949 the Antarctic Division, then part of the Department of Foreign Affairs, was established to organize ANARE acti vities. With Australia taking a more active part in scientific and exploratory work in Antarctica, Hobart became a port of call for vessels of many nations sailing south.

In 1948 the French ship Commander Charcot arrived in Hobart before sailing south to establish a base on the Terre Adélie coast. The French failed to penetrate the ice pack, but they returned in 1949 and were successful in establishing a base at Port Martin. Eleven men wintered there during 1950, and in that year Commander Charcot arrived again in Hobart carrying a relief team. The French also came to celebrate Dumont d'Urville's discovery of Terre Adélie and Tasmania's part in that success (Triebel and Batt 1957: 66).

The Australian government, believing that a presence in Antarctica would enhance its claims to sovereignty, transferred its activities on Heard Island to the Antarctic continent. In 1953 Australia proclaimed sovereignty over the continental shelf and its External Territories, including Australian Antarctic Territory (AAT) and Heard and McDonald islands. On 13 February 1954 Mawson station was established, followed by Davis station during the International Geophysical Year (IGY 1957-1958). Hobart was used regularly for refitting and refueling and as a base for Royal Australian Air Force supply flights to Macquarie Island.

In 1974, when the Australian Commonwealth government decided to transfer the headquarters of the Antarctic Division from Melbourne to Hobart (a difficult and widely unpopular decision that was related to the government's decentralization policy), more formal links on Antarctic matters were established between Tasmania and the Commonwealth government. In 1981 the Australian Antarctic Division, presently within the Department of the Arts, Sport, the Environment and Territories (DASET), moved into new headquarters in the Hobart suburb of Kingston. The Antarctic Division has the broad objective of 'enhancing Australia's scientific, environmental, political, strategic and economic interests (except mineral resource activity) in the Antarctic and, where relevant, the subantarctic, and to preserve its sovereignty over the Australian Antarctic Territory' (Antarctic Division 1991: 22). The Division provides transport and logistic support, maintains five permanent research stations, and conducts and coordinates scientific research programs.
There are 180 permanent employees located within five branches of the Antarctic Division. The Science Branch includes marine science, land-based biology, glaciology, upper atmosphere physics, cosmic ray physics, and science support. Expedition Operations Branch includes expeditions and field operations, logistics, and engineering. Policy and Planning Branch consists of two sections; the first, the policy section, is responsible for policy development, provision of advice for government and the divisional executive, and administration of legislation. The second, the planning and coordination section, maintains a five-year research and operations plan and administers the Antarctic Science Grants Scheme and the Information Services Section. The Polar Medicine Branch provides health care services to expeditioners and conducts research on human adaptation in Antarctica. The Resource Management Branch supplies support services, including financial planning, procurement, and personnel functions. The Antarctic Division houses a polar library with collections from Captain J.K. Davis, F. Stillwell, and Sir T.W. Edgeworth David.

\section{Ocean and air links}

One of the most enduring maritime sights of Hobart has always been the number and type of polar vessels docked in Sullivan's Cove. The bustle of supply activities, ship farewells, and homecomings is a tradition for Hobartians. The Antarctic Division's chartered polar vessels from Australia, Canada, Denmark, Germany, and Norway have been part of this tradition. Chartering of Danish ships, owned and operated by the J. Lauritzen Line, began in 1953 with Kista Dan. The relationship, which also included Magga Dan and Thala Dan, tragically ended when Nella Dan ran aground on Macquarie Island on 3 December 1987 and was scuttled three weeks later. On 23 November 1987, when she returned from her eighty-six th Antarctic voyage, the ship had exceeded 500,000 nautical miles $(910,000 \mathrm{~km})$ on voyages with ANARE, believed to be a greater distance than by any other Antarctic vessel (Jackson 1987: 4). For this reason Nella Dan had a special place in the hearts of many Hobartians. The Danish vessel Nanok-S was also a regular visitor to Hobart. The Germanowned Icebird has served the Antarctic Division since 1984 and continues to operate for Australia. The Norwegian Polar Queen and the Canadian Lady Franklin have both been used on occasion as supply vessels. Lady Franklin was named after the wife of Sir John Franklin, who had helped her husband while he was Lieutenant Governor of Tasmania, before he commenced the fatal Arctic journey for which he is most famous. Other nations operating in Antarctica that have used Hobart as a port include China, France, Italy, Japan, the United States, and the Soviet Union. Greenpeace ships Gondwana and Greenpeace have also used Hobart for supply activities in their Antarctic campaigns. In addition, Hobart has often been visited by many private adventure expedition vessels, including Southern Quest, Dick Smith Explorer, Cheynes $I I$, and $U A P$. 


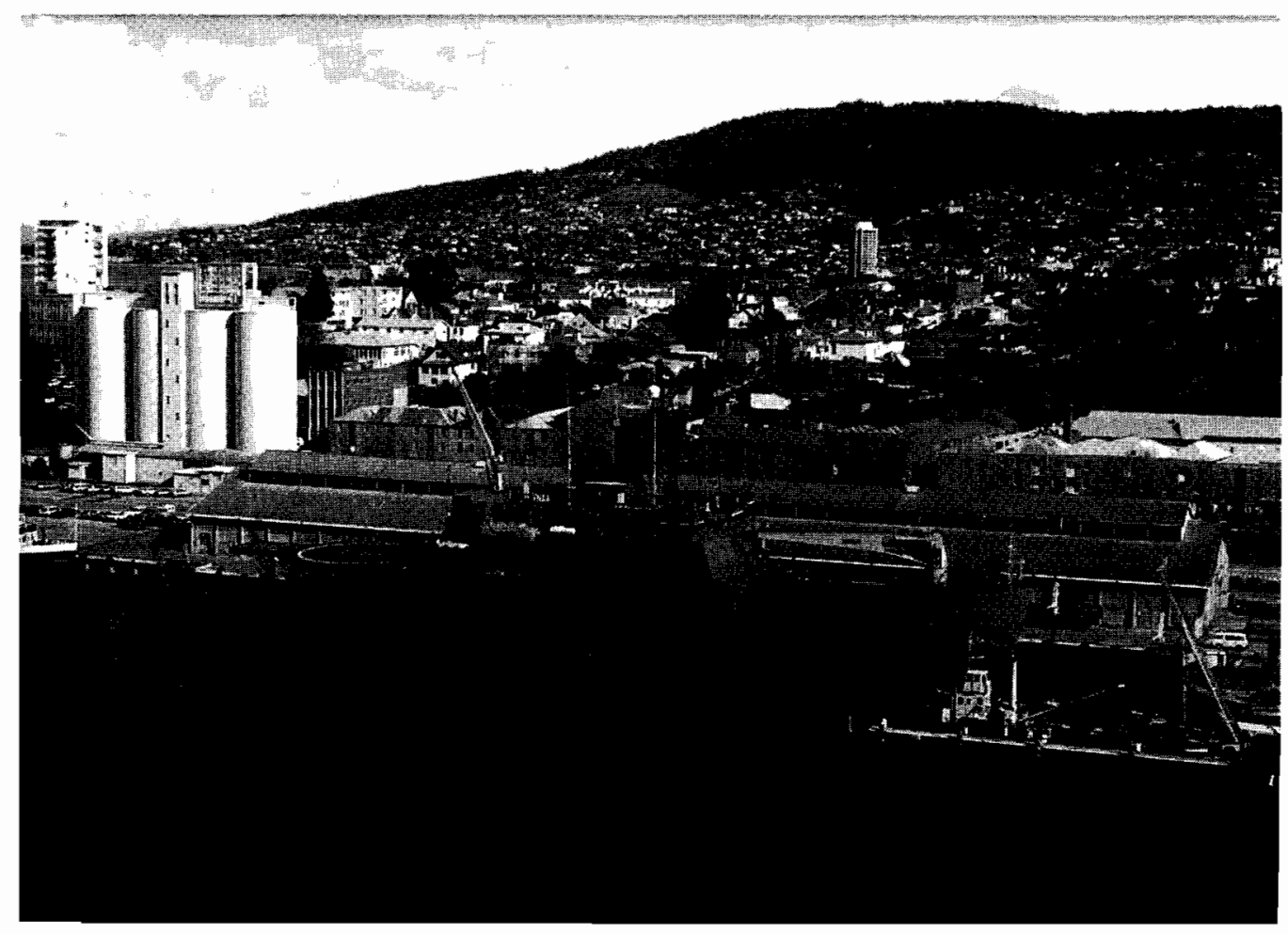

Fig. 4. Aurora Australis, the new Australian supply and research icebreaker.

While the sinking of Nella Dan may have been a sentimental loss to Hobart expeditioners, it also accentuated the need for Australia to have its own Antarctic icebreaking vessel. Thus, on 16 December 1987 the Australian government announced that it would enter contract negotiations with $\mathrm{P} \& \mathrm{O}$ - Polar for the construction and charter of a new research and supply vessel, at the cost of \$A124 million. In just under three years, on 9 October 1990, the new Aurora Australis departed Hobart, arriving nine days later al Casey station in the Antarctic. Aurora Australis is a multi-purpose vessel designed for marine science and supply operations (Fig. 4). At just under $95 \mathrm{~m}$ long, the ship can carry 109 expeditioners, has a cargo hold of $1700 \mathrm{~m}^{3}$ and can break $1.23 \mathrm{~m}$ of first-year ice al 2.5 knots. The icebreaking capacity allows earlier voyages to be undertaken under varying conditions of pack ice.

Antarctic tourist operators have also begun to make Hobart a port of call. One of the first tourist ships to use the port was the Lindblad Explorer in January and February 1971, after which she sailed to the Antarctic ice edge. In December 1990 Frontier Spirit, with 86 passengers, called into Hobart on her way to Antarctica, returning February 1991. The ship carries environmentally responsible tourist excursions to Antarctica and includes a team of Antarctic experts on flora, fauna, environmental issues, legal questions, and politics. Environmental responsibilities are taken seriously and the ship stores all its waste for disposal in Australia. World Discoverer, owned by Society Expeditions Cruises, Inc., also used Hobarl in the same season with a complement of 108 passengers.

With Hobart's maritime Antarctic link firmly in place, others have been exploring the possibilities of air trans- port. Although no commercial flights are available from Hobart to Antarctica, the idea has been widely canvassed and has now been demonstrated to be possible. Dick Smith of Australian Geographic and Giles Kershaw, both avid supporters of air transport to Antarctica, flew a Twin Otter from Hobart to Casey station on 5 November 1988. After the Twin Otter was fitted with skis, Smith and Kershaw flew between Casey, Davis, and Mawson stations assisting in aerial survey work and supply. The 1850-nautical-mile (3350-km) flight took 14 hours but was not the first flight from Australia direct to Antarctica. That honour lies with a US Navy Hercules that, in 1964, flew nonstop from Melbourne to the South Pole. Thus, the air connection with Hobart and Antarctica is technically feasible. Unresolved is the extent of environmental impact associated with runway construction, overflying, and conditions for commercial flights.

\section{Education and research}

Since 1980 Hobart has played a role in international scientific cooperation for the Southern Ocean. The secretariat for the Commission for the Conservation of Antarctic Marine Living Resources (CCAMLR), established in Hobart in 1982, is located on historic Old Wharf in Sullivan's Cove. The Commission has the responsibility of managing the biological resources of the Southern Ocean, with an objective of conserving the marine living resources in accordance with the principle of ecosystemoriented conservation, in which conservation is defined as including rational use (Kriwoken and Keage 1989: 37). Its responsibilities cover the Southern Ocean south of a line approximating the Antarctic Convergence, where cold Antarctic surface waters meet warmer temperate waters. 
CCAMLR is the only international organization with its headquarters in Australia. The 2l parties to CCAMLR meet each October in Hobart to discuss progress and to formulate new measures in managing the living resources of Antarctic waters.

Hobart's status as a host to international conferences was demonstrated when the twentieth meeting of the Scientific Committee on Antarctic Research (SCAR) was held there August-September 1988, with more than 350 scientists attending. SCAR is the international scientific organization with the primary responsibility of coordinating, and providing advice on, Antarctic science. Although a nongovernmental body, membership of the working groups largely consists of scientists affiliated with national Antarctic programs.

In addition to the Antarctic Division and CCAMLR, Antarctic research has commenced at the University of Tasmania, Hobart. In 1988 the University established the Institute of Antarctic and Southern Ocean Studies (IASOS) as a centre for research and teaching on polar issues. IASOS collaborates with a number of other departments within the University. Nominated as a Commonwealth national key centre in 1989, IASOS works closely with the Commonwealth Scientific and Industrial Research Organization (CSIRO), which has divisions of oceanography, fisheries, atmospheric research, and wildlife and ecology; the Bureau of Meteorology; the Bureau of Mineral Resources; and CCAMLR.

IASOS and its various partners were successful in 1991 in obtaining funding from the Australian Science Council for the formation of the Cooperative Research Centre for the Antarctic and Southern Ocean Environment (CRC) at the University of Tasmania. With support from the Science Council for seven years, the CRC brings together five main organizations: the University of Tasmania, the CSIRO Division of Oceanography, the Australian Antarctic Division, the Bureau of Meteorology, and the Bureau of Mineral Resources. Participants contribute \$A5 million per year, with the Science Council providing \$A2.8 million per year. The principal research programs include: (a) Antarctica and the Southern Ocean as monitors and controllers of global environment, (b) Antarctic environmental management, and (c) industrial interaction. The CRC has eight sub-programs: Southern Oceans circulation and ecosystems; sea ice; glaciology/ice-sheet mass; polar atmosphere; natural variability; microbiological processes; human impact (environmental management); and law, policy, and international relations.

In 1989 a proposal for an International Antarctic Centre on Princes Wharf on the southern side of Sullivan's Cove was made by the Tasmanian government. However, the proposal failed because of a lack of finance. This was unfortunate because the $\$ \mathrm{~A} 15$ million polar museum would have provided interpretation and education on Antarctica, a conference venue for national and international meetings, and a community focus for polar events. In addition there would have been a role for the Centre in educating tourists on cruise ships voyaging to Macquarie Island and the Antarctic continent.

In 1990 the Australian Prime Minister announced the cstablishment in Hobart of the Australian Antarctic Foundation. The Foundation, which is affiliated with the Department of Foreign Affairs and Trade, commenced its activities in 1991 and has the objective of promoting debate on Antarctic issues, with particular attention to the significance of developments in that region to Australia.

While the above institutions are involved in education and sponsorship, there have been a number of nongovernmental groups actively campaigning to raise the profile of Antarctica and to place environmental issues high on the political agenda. Groups such as Greenpeace, the Antarctic and Southern Oceans Coalition (ASOC), Ecofleet, and the Australian Conservation Foundation have actively campaigned in the port of Hobart. Direct action has focused on ships that have carried equipment and materials used to build a rock runway at the French Dumont d'Urville station. In addition, ASOC maintains an active lobbying presence at all CCAMLR meetings and publishes $E C O$, an alternative environmental view on its success and failure.

\section{Conclusion}

With more than a century and a half of experience in, and commitment to, the Antarctic continent and the Southern Ocean, Hobart has played an important role in Australia's polar efforts. The Hobart-Antarctic-Southern Ocean connection began in the early 1800 s with the sealing and whaling industry and was strengthened with early exploration and scientific expeditions. With contemporary institutional and educational facilities and tourism development, Hobart's role as a centre for Antarctic and Southern Ocean involvement seems assured.

\section{Acknowledgements}

Lorne Kriwoken is sponsored by an Australian Research Council Fellowship with augmentative funding received from the Antarctic Science Advisory Committee. The authors wish to thank Evlyn Barrett, Bill A. Belderson, Peter Hay, Robert Headland, Andrew Jackson, Peter L. Keage, and Graeme McKinnon for their assistance in preparing this paper.

\section{References}

Abbott, G.J., and N.B. Nairn (editors). 1969. Economic growth of Australia 1788-1821. Melbourne: Melbourne University Press.

Antarctic Division. 1991. A window on Antarctica. Hobart: Antarctic Division.

Bernacchi, L. 1901. To the South Polarregions: expedition of 1898-1900. London: Hurst \& Blackett.

Capricorn Press. 1985. Antarctica: great stories from the frozen continent. Sydney: Readers' Digest.

Chester, J. 1986. Going to extremes: Project Blizzard and Australia's Antarctic heritage. Sydney: Doubleday.

Cole, L. 1990. Proposals for the First Australian Antarctic Expedition. Melbourne: Monash University Press.

Cumpston, J.S. 1968. Macquarie Island. Melbourne: Antarctic Division. 
Evans, H.B., and A.G.E. Jones. 1975. A forgotten explorer: Carsten Egeberg Borchgrevink. Polar Record 17 (108): 221-235.

Headland, R.K. 1989. Chronological list of Antarctic expeditions and related historical events. Cambridge: Cambridge University Press.

Historical Records of Australia. 1921. Sydney: Library Committee of the Commonwealth Parliament, Series 3, Volume 1.

Huntford, R. 1979. Scott and Amundsen: the race to the South Pole. Sydney: Pan Books.

Jackson, A. 1987. Nella Dan makes early start to Antarctic season for seal studies. ANARE News December 1987: 4.

Kriwoken, L.K., and P.L. Keage. 1989. Antarctic environmental politics: protected areas. In: Handmer, J., and R. Birgin (editors). Antarctica: policies and policy development. Canberra: Centre for Resource and Environmental Studies, Australian National University: 31-48.

Laseron, C.F. 1947. South with Mawson. Sydney: Australian Publishing Company.

Lawson, W. 1986. Blue gum clippers and whale hips of Tasmania. Maryborough: The Book Printer.

Lazer, E., and A. McGowan. 1990. Heard /sland archaeological survey 1986-1987. Sydney: University of Sydney Press.

Lovering, J.F., and J.R.V. Prescott. 1979. Last of lands...Antarctica. Melbourne: Melbourne University Press.
Mawson, D. 1915. The home of the blizzard. London: William Heinemann.

Rosenman, H. 1987. Two voyages to the south seas. Melbourne: Melbourne University Press.

Ross, M.J. 1982. Ross in the Antarctic: the voyages of James Clark Ross in Her Majesty's Ships Erebus and Terror 1839-43. Whitby: Caedmon of Whitby.

Savours, A. 1983. John Biscoe, master mariner 17941843. Polar Record 21 (134): 485-491.

Savours, A. 1992. Hobart and the polar regions. In: Winter, G. (editor). Tasmanian insights: essays in honour of Geoffrey Thomas Stilwell. Hobart: State Library of Tasmania, 175-191.

Scholes, A. 1953. Seventh continent. London: George Allen \& Unwin Ltd.

Triebel, L.A., and J.C. Batt. 1957. The French exploration of Australia with special reference to Tasmania. Hobart: Government Printer.

Wace, N., and B. Lovett. 1973. Yankee maritime activities and the early history of Australia. Canberra: Australian National University, Research School of Pacific Studies Aids to Research Series No. A/2.

Winter, G. 1992. Tasmania hails you as her favour'd guest: the British Antarctic Expedition in Hobart. Tasmanian Historical Research Society Papers and Proceedings 38: 138-147.

The accuracy of references in the text and in this list is the responsibility of the authors, to whom queries should be addressed. 